\title{
Analysis of cadmium and lead using atomic absorption spectrophotometer in roadside soils of Jimma town
}

\begin{abstract}
Cadmium and lead are pollutants of great concern to human health. The analysis of Cadmium and lead content in our environment is crucial for policy makers to make decisions concerning the environment and to secure the wellbeing of the inhabitants. In this study lead and cadmium in roadside soil was analyzed. The soil sample was collected at the distance of $18 \mathrm{~m}, 20 \mathrm{~m}, 25 \mathrm{~m}, 26 \mathrm{~m}$ and from the roadside. The collected sample was digested on hot plate. The concentration of lead and cadmium was measured by flame atomic absorption spectroscopy (FAAS). Lead concentrations in soil samples varied from 36.47 to $43.42 \mathrm{mgkg}-1$. Lead analyses showed that there was a considerable contamination in soil affected from traffic intensity. Cadmium and lead were determined using AAS in the surface layer $(0.0-5.0 \mathrm{~cm})$ of soils, situated in areas under different impact of traffic contamination. The Concentration cadmium in soil samples lies between $0.505 \mathrm{mg} / \mathrm{kg}$ to $1.745 \mathrm{mg} / \mathrm{kg}$. The obtained results of Cadmium and lead concentration in the soil around Jimma, Ethiopia; $1.745 \mathrm{mg} / \mathrm{kg}$ and $43.42 \mathrm{mg} /$ $\mathrm{kg}$ respectively, were compared with WHO and EPA. The maximum contaminate level according to WHO, for lead and cadmium in soil is 100 and $3.00 \mathrm{mg} / \mathrm{Kg}$ respectively and appropriate recommendation and conclusion was forwarded. From this site the concentration of lead is higher than cadmium. The average lead and cadmium concentration in soil samples from the four sites of Jimma were all found to be below the maximum tolerable limit according to WHO standards.
\end{abstract}

Keywords: atomic absorption, lead, cadmium, soil samples, traffic contamination
Volume 8 Issue 4 - 2019

\section{Bihonegn Sisay, Eyob Debebe, Asfaw Meresa, Tigist Abera \\ Traditional and Modern Medicine Research Directorate,} Ethiopian Public Health Institute, Ethiopia

Correspondence: Bihonegn Sisay, traditional and modern medicine research directorate, Ethiopian public health institute, addis ababa, Ethiopia, Tel +25191 1806532,

Email bihonegnsisay@gmail.com

Received: July 17, 2019 | Published: July 26, 2019

\section{Introduction}

Anthropogenic sources of heavy metals such as industrial wastes, automobile emissions, mining activity and application of chemical fertilizers, have led to their accumulation in soils. Heavy metals levels in soil are increasing also due to disposal of domestic sewage sludge on agricultural areas. Elevated cadmium and lead levels in soil may result in increased uptake by plants. This is the principal process by which heavy metals enter the food chain. ${ }^{1-2}$

Lead and cadmium level in soil tend to be higher in cities, near road ways and around industrial sources that use or release lead and cadmium. Soils whether in urban or agricultural area, represent a major sink for metals released in to the environment from a variety of anthropogenic sources. Once in soil some of these materials will be persistent because of their fairly immobile nature. ${ }^{3}$

According to the kind of vehicle in traffic; the quality of heavy metals varies in street dust. The use of leaded Gasoline gives a boost to the importance of lead level especially in street dust even at the start of $21^{\text {st }}$ century. Air Pollution has long been recognized as lethal form of pollution, much of the problems of societal concern today are the heavy metals associated with air pollution. ${ }^{4}$

Many researches on analysis of lead and cadmium were done most of them mainly to wards determination of lead and cadmium in roadside soil. However there is no more consideration about health effect of lead and cadmium in society.

The result of the analysis of cadmium and lead in the soil of a given area is very crucial for comparison with WHO's permissible limit and take corrective measures for the wellbeing of inhabitants. This study may be serve as an important tool for policy makers to make decisions concerning the environment and to secure the wellbeing of the community or promoting health care services by minimize the level of cadmium and lead in the soil.

\section{Material and methods}

\section{Sampling sites}

The soil samples were collected from four different sites of Jimma town, Oromia regional state, south western Ethiopia in December 2018. The soil samples were kept in polythene bags and labeled to avoid a mix up of the different soil samples. They finally were brought to the laboratory.

\section{Soil sample collection}

Soil samples was collected from four different site Mercato, Koch, Jimma hospital and Yetebaberut of the sample collect different distances from the road side to a depth of $0.0-5.0 \mathrm{~cm}$ using a soil auger. The soil samples were keeping in a polythene bags and labeled to avoid a mix up of the different soil samples. Then it was bright to the laboratory and keeps in the air dried place prior to analysis for lead and cadmium.

\section{Soil sample preparation}

Unwanted materials such as stones, leaves and debris was remove from the soil samples by hand picking and dried on an air dried oven. 
The dried soil samples were then powder in to finer particles using a laboratory mortar and pestle and sieve to homogenize the sample. The powdered soil samples were farther dry using an air dried oven for 8hours at $105^{\circ} \mathrm{C} .{ }^{5}$

\section{Experimental procedure}

To make lead and cadmium analyses first each soil sample was homogenized and dry at $105^{\circ} \mathrm{C}$. After that $1.0 \mathrm{~g}$ of the sieved sample was placed in $300 \mathrm{ml}$ beaker and boiled at $230^{\circ} \mathrm{C}$ with $15 \mathrm{ml}$ of nitric acid (HNO3,69\%) and $25 \mathrm{ml}$ of perchloric acid (HClO4,58\%). After completely turned to ash, the digested solution was filtered and made the volume up to $50 \mathrm{ml}$ in a volumetric flask. The metal concentrations were determined by atomic absorption spectrophotometer. ${ }^{5,6}$

\section{Statistical analysis}

Statistical analysis was performed using SPSS 18.0 (SPSS Inc. Chicago, IL, USA) software. One-way ANOVA was used. P-Values less than 0.05 were considered significant.

\section{Results}

The analysis of soil samples for lead content by flame atomic absorption spectrophotometer The analysis showed the presence of lead in all the four soil samples collected from different sites at varying concentrations ranging from $36.47 \pm 0.000243$ to $43.42 \pm 0.000029 \mathrm{mg} /$ $\mathrm{kg}$ (Table $1 \&$ Figure 1).

Table I Lead standard solution

\begin{tabular}{llllll}
\hline No & Name & Abs & SD & RSD & $\begin{array}{l}\text { con } \\
\mathbf{( m g / L )}\end{array}$ \\
\hline I & Cal-zero & 0.000003 & 0.000013 & 380.9 & 0 \\
2 & Cal-stdI & 0.000057 & 0.000067 & $1 \mathrm{I} 7.1$ & $0.00 \mathrm{I}$ \\
3 & Cal-std2 & 0.004414 & 0.000004 & 0.092 & 0.5 \\
4 & Cal-std3 & 0.008724 & 0.00092 & 1.056 & $\mathrm{I}$ \\
5 & Cal-std4 & 0.02308 & 0.000009 & 0.394 & 2.5 \\
\hline
\end{tabular}

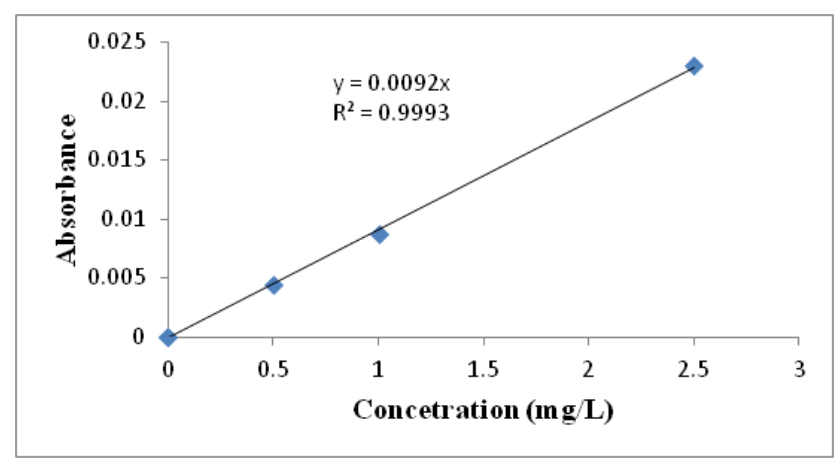

Figure I Calibration curve for lead standard solution.

The analysis of soil samples for Cadmium content by flame atomic absorption spectrophotometer. The analysis showed the presence of cadmium in all the four soil samples collected from different sites at varying concentrations ranging from $0.505 \pm 0.000257$ to $1.745 \pm 0.000706 \mathrm{mg} / \mathrm{kg}$ (Table 2,3 \& Figure 2)
Table 2 Cadmium standard solution

\begin{tabular}{llllll}
\hline No & Name & Abs & SD & RSD & Cons(mg/L) \\
\hline I & Cal-Zero & 0.00247 & 0.001466 & 59.35 & 0 \\
2 & Cal-stdl & 0.01456 & 0.000409 & 2.812 & 0.05 \\
3 & Cal-std2 & 0.0 .08796 & 0.000073 & 0.084 & 0.5 \\
4 & Cal-std3 & 0.1726 & 0.000174 & 0.068 & 1 \\
5 & Cal-std4 & 0.3283 & 0.005955 & 0.053 & 2 \\
6 & Cal-std5 & 0.635 & 0.000888 & 0.938 & 5 \\
\hline
\end{tabular}

Table 3 Concentration levels of lead and cadmium in different places of Jimma town

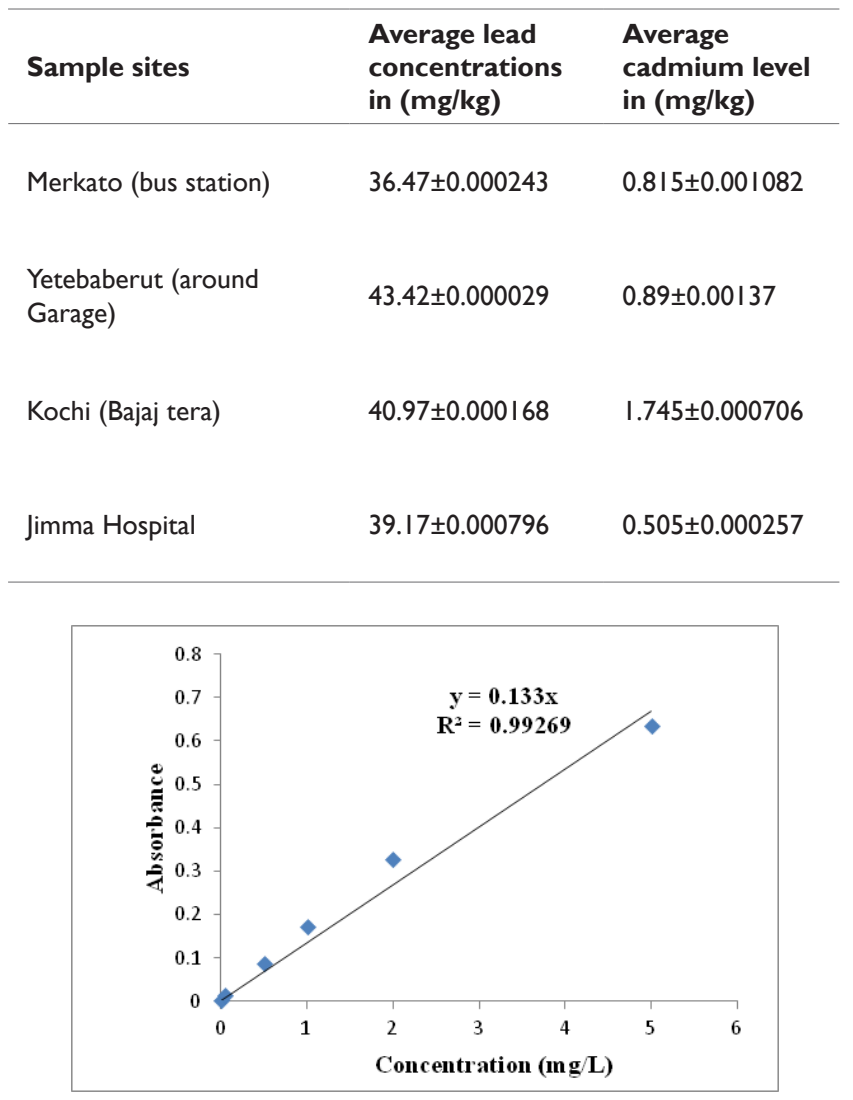

Figure 2 Calibration curve for cadmium standard solution.

Comparison of heavy metal in roadside soil samples Ethiopia (Jimma) with other countries.

The result obtains from the analysis of different soil sample by using Atomic spectroscopy (AAS). The method was summarized in the Table 3 above. The heavy metal concentration were determine the analysis of lead and cadmium were not done before in Jimma town (Table 4). 
Table 4 Comparison of heavy metal in roadside soil samples Ethiopia (Jimma) with other country

\begin{tabular}{llll}
\hline Country & $\begin{array}{l}\text { Lead }(\mathbf{m g} / \\
\mathbf{k g})\end{array}$ & $\begin{array}{l}\text { Cadmium } \\
(\mathbf{m g} / \mathbf{k g})\end{array}$ & Reference \\
\hline $\begin{array}{l}\text { Turkey } \\
\text { Northern }\end{array}$ & 45 & 0.527 & 5 \\
$\begin{array}{l}\text { England } \\
\text { Ethiopia (Jimma) }\end{array}$ & $\mathrm{I} .198 .0$ & 3.8 & 14 \\
$\begin{array}{l}\text { European } \\
\text { Highway E30 }\end{array}$ & 155.75 & 0.909 & Present study \\
\hline
\end{tabular}

\section{Discussion}

As shown on the above table (Table 1) the soil taken from Yetebaberut (garage area) recorded as the highest lead content with concentration of $43.42 \pm 0.000029 \mathrm{mg} / \mathrm{kg}$ followed by Koch (bajaj tera) with a level $40.97 \pm 0.000627 \mathrm{mg} / \mathrm{kg}$, Hospital area with level $39.17 \pm 0.000721 \mathrm{mg} / \mathrm{kg}$ and Merkato with the level $36.47 \pm 0.000243$ which was taken from different site. No elevated level of lead in soil (greater than $50 \mathrm{mg} / \mathrm{kg}$ ) was detected in all four sites investigated. Soil lead concentration in all sites was found to be within the estimated natural concentration range of 35 to $50 \mathrm{mg} / \mathrm{kg}^{7,8}$ However, soil samples of Merkato, garage and Koch (bajajitera) that were taken from vehicular and gasoline area contain by far large concentration of lead when compared with non-gasoline area of Hospital area. Due to high construction expiation around in hospital area high concentration lead than in Merkato.

This is primarily due to vehicular emissions and partly igneous activity. In contrast, soil samples of Merkato contain in low concentration. Because this site was remote from vehicular, gasoline and other causes.

As shown on the above table (Table 2) the soil taken from Koche (bajajitera) recorded as the highest cadmium content with concentration of $1.745 \pm 0.000706 \mathrm{mg} / \mathrm{kg}$ followed by Yetebaberut (around Garage) with a level $0.89 \pm 0.00137 \mathrm{mg} / \mathrm{kg}$, Merkato (around bus station) with level $0.815 \pm 0.001082 \mathrm{mg} / \mathrm{kg}$ and with the level which was taken $0.505 \pm 0.000257 \mathrm{mg} / \mathrm{kg}$ from different site. No elevated level of cadmium in soil (greater than $5 \mathrm{mg} / \mathrm{kg}$ ) was detected in all four sites investigated. Soil cadmium concentration in all sites was found to be within the estimated natural concentration range of 0.5 to $2 \mathrm{mg}$ / $\mathrm{kg}$. However, soil samples of Merkato, garage and Koch (bajajitera) that were taken from vehicular and gasoline area contain by far large concentration of cadmium when compared with non-gasoline area of Hospital area. Due to high construction expiation around in hospital area low concentration cadmium than in kochi. Because this site was remote from vehicular, gasoline and other causes. In contrast, soil samples of Kochi contain in high concentration. This is primarily due to vehicular emissions and partly igneous activity. Nonetheless, the average lead and cadmium concentration in soil samples from the four sites studied were all found to be below the maximum tolerable limit according to world health organization (WHO) standards. ${ }^{9-12}$

The result of this study provides answers to our testable hypotheses and the finding suggests that the level of cadmium and lead is below the maximum tolerable/permissible limit of WHO. But, certain precautionary measures must be conducted in order to prevent possible ingestion of soil containing lead and cadmium. To the best of my knowledge this study is the first in the given area and size of the samples.

\section{Conclusion}

As the study result indicated there is no sampling sites recorded a lead and cadmium concentration beyond the world health organization (WHO) permissible limit of 100 and $3.12 \mathrm{mg} / \mathrm{kg}$ respectively. ${ }^{11,13-15}$ An average soil lead and cadmium concentration in these studied sites was in the estimated natural concentration $35 \mathrm{mg} / \mathrm{Kg}$ to $50 \mathrm{mg} /$ $\mathrm{Kg}$ and $0.5 \mathrm{mg} / \mathrm{Kg}$ to $5 \mathrm{mg} / \mathrm{Kg}$. However, the concentration of such a heavy metal in these sampling sites were below the world health organization permissible limit the soil sample taken from sampling site of roadside exposed to gasoline and vehicular emission shows a considerable difference in concentration of lead and cadmium in relative to the soil of non-gasoline area. This shows that the level of lead and cadmium in these sites were primarily due to vehicular emission and goals line effluent. In this study the concentration of lead is higher than cadmium in the roadside soil in Jimma south west Ethiopia.

Generally for this study the concentration of lead and cadmium in around Garage area and bajajtera soil in Jimma town is almost very slightly affect human and animal health. Even if the result is below the limit, certain precautionary measures must be conducted in order to prevent possible ingestion of soil containing lead and cadmium. Finally, we recommend further study on this area by increasing the sample size to make it more representative.

\section{Acknowledgments}

None.

\section{Conflicts of interest}

The author declares that there is no conflict of interest.

\section{References}

1. Kabata-pendias A. Trace Elements in Soil and Plants. 3rd ed. Boca Raton, FL: CRC Press; 2000:356.

2. Tu C, Zheng CR, Chen HM. Effect of applying chemical fertilizers on forms of lead and cadmium in red soil. Chemosphere. 2000;41(1-2):133138 .

3. Alain Manceau. MCB: Environmental science and Technology. 1996;30:76-54.

4. Garba NN, Asma'u, K, Garba ZN, et al. Analysis of heavy metals concentration deposited in roadside soil. 2013;2(2):23-27.

5. Mehmet YN, Determination of lead, cadmium and copper in roadside soil and plants in Elazig, Turkey. Environ Monit Assess. 2008;136(1-3):401410 .

6. Littlejohn D, Davidson JB, Quevauviller P. Soil sediments. Journal of analytical chemistry. 2006;6:62.

7. Mutua Simon Mutuku. Lead, cadmium and zinc speciation in garage soils, their levels in kales and water along katothyani stream, machakos town, Kenya. 2013:1-78.

8. Needle HL, Gunnoe C, Levitson A, et al. Phytoremediation of contaminated soil and water. In: Nordberg G. Handbook of toxicology of metals. Elsevier, Academic Press; 2007:136.

9. Marcus Jopony. Analysis of Low Lead and Cadmium Concentrations in soil Extracts by Graphite Furnace Atomic Absorption Spectrophotometry. Pertanika J Sci \& Techno. 1993;1(2):199-207.

10. Rossi/Kuwata. Determination of Lead in Soil by Atomic Absorption Spectroscopy. A Chemical \& Engineering News. 2006;47-49. 
11. Fakayade S, Onianwa P. Heavy metal contamination of soil and bioaccumulation in guinea grass (panicum maximum) around Ikeja industrial estate. J environmental geology. 2002;43(1-2):145-150.

12. Abdul Kashem MD, Singh BR. Heavy metal contamination of soil and vegetation in the vicinity of industries.1999;115(1-4):347-36.

13. Lead and other heavy metal in community Garden soil. Connecticut. 2018
14. Wiliam HG Hale, Khalid Farooq Akbar, Alistair D, et al. Heavy Metal Contamination of Roadside Soils of Northern England. Soil \& Water Res. 2006(4):158-163.

15. Jankowski K, Ciepiela AG, Jankowska J, et al. Content of lead and cadmium in aboveground plant organs of grasses growing on the areas adjacent to route of big traffic. Environ Sci Pollut Res Int. 2015;22(2):978-987. 